\title{
Hypermethylation at CpG islands of GSTP1 gene's promoter is the typical property of breast cancer in Vietnamese population
}

\section{- Doan Thi Phuong Thao}

HCM Medicine and Pharmacy University

- Truong Kim Phuong

- Lao Duc Thuan

- Le Huyen Ai Thuy

HCM Open University

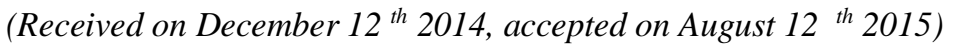

\section{ASTRACT}

The demand for biomarker that applied in prognosis, early diagnosis, predicting and/or monitoring the therapeutic response and detection of recurrent cancer is the worldwide expection. One of the biomarker, which the worldwide researches focused on, is the hypermethylation at $\mathrm{CpG}$ island of promoter which undergoes the DNA methylation changes in carcinogenesis. In current study, the target gene is GSTP1 (Glutathion-Stransferase pi 1 gene), with one of the most function is particularly involved in detoxification. Because of this function, GSTP1 (obviously based on the frequencies of methylation) has been chosen as a potential candidate gene for several clinical trials in predicting of the response to the demethylation drugs in several cancers, including breast cancer. In this study, we foscused on the evaluation of the methylation status of 115 biopsy specimens collected from university medical center HCMC, including 95 breast cancer specimens and 20 noncancerous breast tissue. The results showed that 41 of 95 (43.2\%) breast cancer specimens are hypermethylated, no methylation was found on the noncancerous breast tissue $(p<0.01)$. These results allowed us to predict the totally corresponding to the application of the treatment, which based on the demethylation drug, one of the epi-drug line, in Vietnamese patients in the near future.

Keywords: GSTP1 (Glutathion-S-transferase pi 1 gene), MSP (Methylation specific PCR), breast cancer, demethylation drug, biomarker.

\section{INTRODUCTION}


Breast cancer is the most frequent cancer among women in Vietnam. According to the Globocan (2012), it was observed that, in 2012, people newly diagnosed with breast cancer has significant increased to 125,000 . Currently, although chemotherapy or chemoradiotherapy are the most effective treatments of breast cancer, due to the patient's clinical characteristics, genetic differences in drug transported, therefore it is limited by significant heteogeneity variation in response and toxicity [6, 7, 21]. For further innovatory therapy, an understanding of the molecular events as an aberrant epigenetic modification, leading to the development of cancer, including breast cancer, is the worldwide expectation. DNA hypermethylation has been reported as the potential biomarker for the diagnosis and prognosis of cancer [1, 10], it was involved in the GSTPI case. The hypermethylation of GSTP1 promoter was also detected in several cancers including breast cancer, prostate cancer, lung cancer... The frequency of the hypermethylation of GSTP1 was found out as $26 \%$ [17], $18 \%$ [15] in breast cancer and $36.1 \%$ [11] in prostate cancer... Nowadays, the DNA methylation biomarker is also considered as an application in predicting and/or monitoring the therapeutic response, as well as detection of recurrent cancer, because DNA methylation changes were observed during the carcinogenesis [10].

GSTP1 (Glutathion S-transferase P1), which is belonged to the tumor suppressor genes family, involves in the detoxification of reactive carcinogen metabolites and plays an important role in the cellular defense system $[2,17,21]$. The hypermethylation of GSTP1 has been reported as the potential DNA-based biomarkers in cancer, including breast cancer, and applied in predicting the epi-drug response [10]. Several studies showed that the hypermethylation of the $\mathrm{CpG}$ islands belonged to the promoter region of GSTP1 leading to the decrease in gene expression, resulted in breast cancer $[2,3,5,17]$. For the aims to improve the further successful promising biomarkers in Vietnamese population, in present study, we determined quantitatively the methylated frequency of GSTPl gene's promoter and evaluated the correlation with the clinicopathological data of Vietnamese breast cancer patients.

\section{MATERIALS AND METHODS}

\section{Sample collection}

A total of 115 samples including 95 breast cancer specimens and 20 non-cancer samples were collected and admitted from Ho Chi Minh city Medical hosptital center. All the breast cancer specimens were reviewed and immunohistochemical analysed with two predictive factors including HER2/neu and p53 antibodies (Ventana CONFIRM anti-HER-2/neu (4B5) and Bp53-11) according to the protocols of ASCO quality guideline [13]. 20 healthy specimens were obtained from women who were underwent the biopsy of the mammary gland because of mammographic screening and for whom histology confirmed the presence of only normal tissue. These tissues were obtained from the surgical progress, and then, embedded in the paraffin and finally, stored at $-20{ }^{\circ} \mathrm{C}$ for further usage.

\section{DNA extraction, bisufite modification and MSP assay}

Total of genomic DNA was extraeted with phenol/chloroform method from all the paraffin embedded breast cancer specimens and the healthy samples. The concentration and purity of DNA extraction were analysed by the absorbance at $260 \mathrm{~nm}$ and $280 \mathrm{~nm}$. The purity of which sample with the ratio $\mathrm{OD}_{260} / \mathrm{OD}_{280}$ values of 1.8 to 2.0 was 
used to the bisulfite modification by using the DNA modification kit (Epitect Kit, Qiagen).

For MSP (methylation specific PCR) assay, the primer set for MSP analysis of GSTP1 was used to qualify the methylation status of methylation and unmethylation of given gene
(Table 1). The amplifications were done in a total volume of $15 \mu \mathrm{L}$, containingapproximately $50 \mathrm{ng}$ bisulfite modified template DNA, 0.75 unit iTaq DNA polymerase (Biorad) and $0.2 \mu \mathrm{L}$ each primer.

Table 1. The primer sequence for methylation and unmethylation of GSTP1 evaluation.

\begin{tabular}{|c|c|}
\hline Name & Sequence $\left(5^{\prime}-3^{\prime}\right)$ \\
\hline MF & 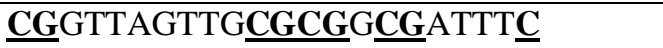 \\
\hline MR & 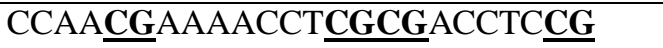 \\
\hline UF & TIGGTTAGTTGTGTGGTGATTTTG \\
\hline UR & 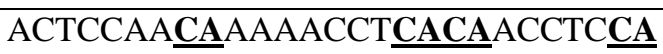 \\
\hline
\end{tabular}

Note: $\mathrm{CpG}$ sites were bold and underlined.

MSP reaction was subjected to initial incubation at $95{ }^{\circ} \mathrm{C}$ for $5 \mathrm{~min}$, followed by 40 cycles at $95{ }^{\circ} \mathrm{C}$ for $30 \mathrm{~s}, 51^{\circ} \mathrm{C}$ for $30 \mathrm{~s}, 72{ }^{\circ} \mathrm{C}$ for $30 \mathrm{~s}$ and $72{ }^{\circ} \mathrm{C}$ for $6 \mathrm{~min}$ for final incubation. Each PCR product was directly loaded onto a $2.0 \%$ agarose gel, stained with ethidium bromide, and directly visualized under UV illumination.

\section{Statistical analysis}

The methylation frequency of GSTPI was calculated and the differences in the presence of methylation were determined by two sided Fisher test and Chi squared tests for variables. Moreover, the OR (Odd ratio) and $95 \%$ CIs (confidence intervals) were also calculated. Statistical analyses were performed by using Medcalc® Version 12.7.0.0. Statistical significance was assumed at two-side $\mathrm{P}$ value of $p$ $<0.05$.

\section{RESULTS AND DISCUSSIONS}

The methylation frequency was qualified in total of 95 breast cancer specimens and 20 noncancer specimens. As the result, the frequency of methylated and unmethylated GSTP1 was $43.2 \%$ (41 cases of 95 specimens). Otherwise, in noncancer specimens, none of methylation status was found (Fig. 1). 


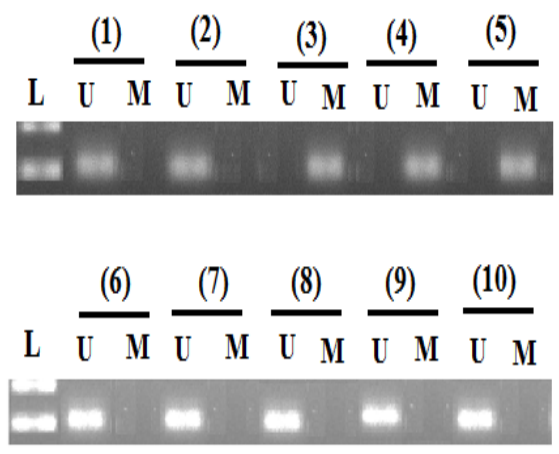

Fig. 1. Methylated promoter of GSTP1 gene analysis on some clinical samples by MSP. U: unmethylated; M: methylated; L: 100 kp Ladder; (1), (2), (3), (4), (5) breast cancer samples; (6), (7), (8), (9), (10) non-cancer specimens.

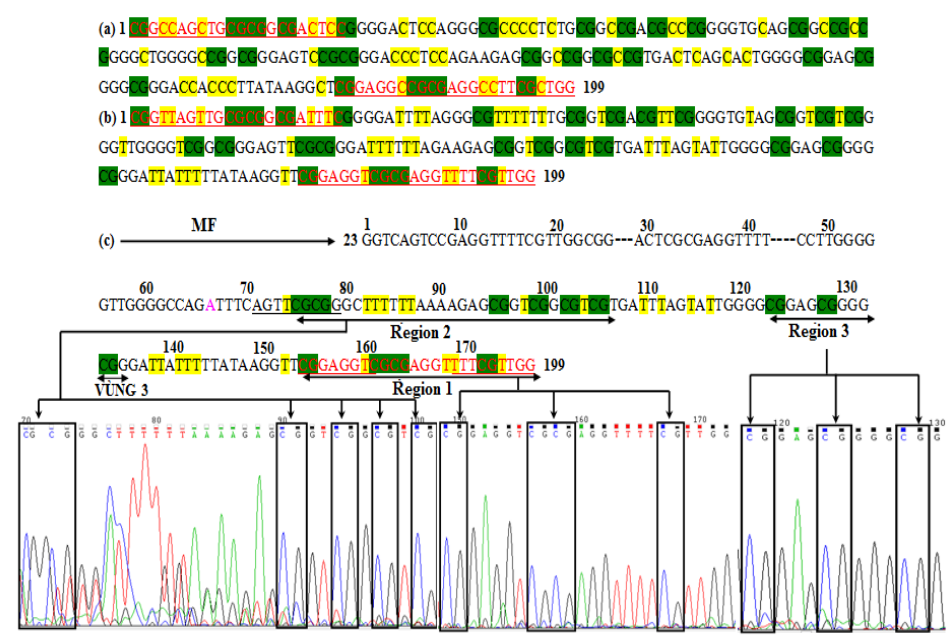

Fig. 2. Sequencing profile of methylated of GSTP1. CpG sites were in green highlight; the Cytosine did not located at the $\mathrm{CpG}$ sites were in yellow. (a) DNA sequence was without bisulfite modified; (b) DNA sequence was bisulfite modified; (c) The GSTP1 sequencing by using the forward methylated primer (MF). Region 1 was binding site of reverse methylated primer. Region 2: $6 \mathrm{CpG}$ sites were in examined region. Region $3: 3 \mathrm{CpG}$ sites were in examined region.

The methylation status was confirmed by it was also concluded that the bisulfite DNA sequencing (Fig. 2). By DNA sequencing, we totally observed $9 \mathrm{CpG}$ sites, which were totally methylated, were in examined region including regions 2 and 3. Specially, we detected 4 methylated $\mathrm{CpG}$ sites in the region 1 which was according to the binding site of the methylated reverse primer. Concerning to the signal of peaks in MSP product sequencing, the signals were unique, clear and specific. Based on these results, modification was successful carried out.

In the context of methylation status, the aberrant methylation status of GSTP1 has been reported in many cancer including breast cancer, comparison to the recent report, the methylation frequency of GSTP1 in the present study was higher than the research of Yoon et al. (2012) [20] as $27.8 \%$, Lasabova et al. (2010) [14] as $24.45 \%$. Especially, comparison to a research in Asian

\section{Trang 108}


country such as Thailand by Pongtheerat et al. (2011) [17], the methylation status of GSTP1 was also higher than Ponthreeat's research as $26 \%$. To evaluate the correlation between the DNA methylation and clinical parameters, the immunochemical staining of HER2/neu, p53 were carried out (Table 2). Because the overexpression of HER2/neu was found to be present in $15 \%$ - 30 $\%$ newly diagnosed breast cancer and mutations of p53 gene and/or p53 has been observed in 20 $\%-50 \%$ of primary breast carcinomas $[9,19]$, thus the expression of HER2/neu and p53 were used as the input values to confirm the breast cancer status

Table 2. The correlation between five genes promoter methylation and HER2/neu, p53

characteristic

\begin{tabular}{|c|c|c|c|c|c|c|}
\hline \multirow{2}{*}{} & \multicolumn{2}{|c|}{ HER2/Neu } & \multicolumn{2}{c|}{ p53 } & \multicolumn{2}{c|}{ HER(-)p53(-) } \\
\cline { 2 - 7 } & Negative & Positive & Negative & Positive & No & Yes \\
\hline $\mathrm{U}(\%)$ & $52(68.4)$ & $19(48.7)$ & $30(88.2)$ & $41(50.6)$ & $45(54.9)$ & $26(78.8)$ \\
\hline $\mathrm{M}(\%)$ & $24(31.6)$ & $20(51.3)$ & $4(11.8)$ & $40(49.4)$ & $37(45.1)$ & $7(21.2)$ \\
\hline$p$ value & \multicolumn{2}{|c|}{0.06} & \multicolumn{2}{c|}{$\mathbf{0 . 0 0 0 3}$} & \multicolumn{2}{c|}{$\mathbf{0 3}$} \\
\hline
\end{tabular}

Regarding to the DNA hypermethylation and HER/neu staining, we observed that there was not associated with the HER2/neu $(p=0.06)$. By contrast, the overexpression of p53 was strongly correlated with the methylation status $(p=$ 0.0003). Interesting, taken these two prognosis biomarkers together, the frequent methylation of GSTP1 promoter hypermethylation in breast cancer were strongly associated to HER2/neu()p53(-) $(p=0.03)$. It meant that the DNA based marker methylation was negative associated with the other protein based markers.

In addition, to evaluate the applicability of GSTP1 methylation in breast cancer patients as biomarkers for breast cancer, the odd ratio (OR) was calculated. Even though only 20 non-cancer specimens were compared with 95 tumor specimens, we tentatively applied the $C h i^{2}$ test to calculate the OR value. As the result, we found out OR was 31.22 at $95 \%$ confidence with the significant statistic $(p=0.02)$. Moreover, the significant correlation between OR and breast cancer was considered. It meant that in the model the odds for a positive hypermethylation of GSTP1 in breast cancer were 31.22 times higher than in the cases of cancer without GSTP1 methylated. Thus, due to those results, it was noted that the hypermethylation of GSTP1 promoter was the specific characteristic of Vietnamese breast cancer patients. It is highlighted that this characteristic was adapted to not only as the potential biomarker in prognosis, diagnosis but also predicting/monitoring the demethylation drug responses as the function of GSTP1, in Vietnamese patients in the near future.

\section{CONCLUSION}

95 tumors from Vietnamese breast cancer patient and 20 non-cancer specimens were carried out for GSTP1 promoter methylation analysis. It was found that $43.2 \%$ of Vietnamese breast cancer specimens which were positive to GSTPl hypermethylation. This hypermethylation was considerably associated with the OR value which was counted for 31.22 at $95 \%$ CI. 
Those data indicated that the role of aberrant methylation at $\mathrm{CpG}$ island of GSTPl as the potential biomarker for prognosis and early diagnosis for Vietnamese breast cancer patients. Besides, for further study, it was carried out to study, predict and have an overall vision about the response of demethylation drug in Vietnamese breast cancer population.

Acknowledgement: This study was funded by The Department of Science and Technology, Ho Chi Minh City, Vietnam.

\section{Sự methyl hóa vượt mức tại đảo cpg thuộc vùng promoter của gen gstp1 là một đặc tính đặc trưng của bệnh ung thư vú người Việt Nam}

- Đoàn Thị Phương Thảo

Trường Đại học $\mathrm{Y}$ Dược

- Trương Kim Phượng

- Lao Đức Thuận

- Lê Huyền Ái Thúy

Trường Đại học Mở TP HCM

\section{TÓM TÁ́T}

Nhu cầu về việc có được một dấu chứng sinh học (biomarker) nhằm ứng dụng trong việc tiên lượng, chẩn đoán sớm, dụ̣ đoán và/hoặc theo dõi điều trị cũng như xác định tính tái phát của bệnh ung thư hiện vẫn đang là một đòi hỏi cấp thiết của nhân loại. Một trong những dấu chứng sinh học hiện vẫn đang được thế giới tập trung nghiên cứu, đó là dựa trên sự methyl hóa bất thường tại các đảo CpG thuộc vùng promoter của các gen có liên quan đến sự hình thành và phát triển của bệnh ung thư. Trong nghiên cứu này, gen đích được lựa chọn là GSTP1 (Glutathion-Stransferase pi 1 gene) với một trong những chức năng đặc biệt quan trọng của nó là giải độc (detoxification). Với chức năng này mà gen GSTP1 (với thông số methyl hóa bất thường) đã được chọn thử nghiệm lâm sàng nhằm dự đoán tính đáp ứng với dòng thuốc giải methyl trên nhiều loại ung thu', trong đó có ung thư vú, cho kết quả rất khả quan. Chúng tôi tập trung khảo sát tính chất methyl hóa bất thường của gen GSTP1 bằng kỹ thuật MSP (Methylation specific PCR) tùr 115 mẫu sinh thiết mô vú trong đó có 95 mẫu của các bệnh nhân mắc ung thư vú và 20 mẫu mô vú lành tính (của các bệnh nhân mắc các bệnh khác về vú mà không phải ung thư) do bệnh 
viện Đại học Y Dược, TP. HCM cung cấp, và ghi nhận 41 trong 95 mẫu mô ung thư (43.2 \%) bị methyl hóa bất thường và không có trường hợp nào được phát hiện có methyl hóa trên 20 mẫu mô lành tính $(p<0.01)$. Kết quả này cho phép chúng tôi dụ đoán về sự phù hợp cao của việc áp dụng phương thức trị liệu bằng thuốc giải methyl, một trong các thuốc thuộc dòng epi-drug, của các bệnh nhân mắc ung thư vú người Việt Nam, trong một tương lai gần.

Tùr khóa: GSTP1 (Glutathion-S-transferase pi 1 gene), MSP (Methylation specific PCR), ung thư vú, thuốc giải methyl, biomarker.

\section{REFERENCES}

[1]. B.S. Baylin, P.A. Jones, A decade of exploring the cancer epigenome biological and translational implications. Nature Reviews Cancer, 11, 726-34 (2011).

[2]. K. Chiam, M.M. Centenera, L.M. Butler, W.D. Tilley, T. Bianco-Miotto, GSTPI DNA Methylation and expression status Is indicative of 5-aza-2'-deoxycytidine efficacy in human prostate cancer cells. PLOS one, 6, 9, 25634 (2011).

[3]. P.M. Das, R. Singal, DNA Methylation and Cancer. J. Clin. Oncol., 22, 4632-42 (2004).

[4]. V.A. DeWoskin, R.P. Million, The epigenetics pipeline. Nat Rev Drug., 12, 9, 661-2 (2013).

[5]. M. Esteller, P.G. Corn, S.B. Baylin, J.G. Herman, A gene hypermethylation profile of human cancer. Cancer Res., 61, 8, 3225-9, (2001).

[6]. W.E. Evans, H.L. McLeod, Pharmacogenomics - drug disposition, drug targets, and side effects. N. Engl. J. Med., 348, 6, 538-49, (2003).

[7]. W.E. Evans, M.V. Relling, Pharmacogenomics: translating functional genomics into rational therapeutics. Science, 286, 5439, 487-91 (1999).

[8]. J.Y. Fang, Z.H. Cheng, Y.X. Chen, R. Lu, L. Yang, H.Y. Zhu, L.G. Lu, Expression of DNMT1, demethylase, MeCP2 and methylation of tumor-related genes in human gastric cancer. World J. Gastroenterol., 10, 23, 3394-8 (2004).

[9]. H. Fiegl, S. Millinger, G. Goebel, E. MüllerHolzner, C. Marth, P.W. Laird, M. Widschwendter, Breast cancer DNA methylation profiles in cancer cells and tumor stroma: association with HER-2/neu status in primary breast cancer. Cancer Research, 66, 1, 29-33 (2006).

[10].S. Fukushige, A. Horii, DNA methylation in cancer: a gene silencing mechanism and the clinical potential of its biomarkers. Tohoku J. Exp. Med., 229, 3, 173-85 (2013).

[11].C. Goessl, H. Krause, M. Müller, R. Heicappell, M. Schrader., J. Sachsinger, K. Miller, Fluorescent methylation-specific polymerase chain reaction for DNA-based detection of prostate cancer in bodily fluids. Cancer Res., 60, 5941-5 (2000).

[12].J. Goffin, E. Eisenhauer, DNA methyltransferase inhibitors-state of the art. Ann. Oncol., 13, 1699-716 (2002).

[13].F.L. Greene, D.L. Page, I.D. Fleming, A. Fritz, C.M. Balch, D.G. Haller, Cancer Staging Manual, 6th ed., Springer, New York, (2010).

[14].Z. Lasabova, P. Tilandyova, K. Kajo, P. Zubor, T. Burjanivova, J. Danko, L. Plank, Hypermethylation of the GSTP1 promoter region in breast cancer is associated with 
prognostic clinicopathological parameters. Neoplasma., 57, 1, 35-40 (2010).

[15].C. Matuschek, E. Bölke, G. Lammering, P.A. Gerber, M. Peiper, W. Budach, H. Taskin, H.B. Prisack, G. Schieren, K. Orth, H. Bojar, Methylated APC and GSTP1 genes in serum DNA correlate with the presence of circulating blood tumor cells and are associated with a more aggressive and advanced breast cancer disease. Eur. J. Med Res., 15, 277-86 (2010).

[16].J.A. Plumb, N. Steele, P.W. Finn, R. Brown, Epigenetic approaches to cancer therapy. Biochem. Soc. Trans., 32, 6, 1095-7 (2004).

[17].T. Pongtheerat, S. Pakdeethai, W. Purisa, S. Chariyalertsak, S. Petmitr, Promoter methylation and genetic polymorphism of glutathione S-transferase P1 gene (GSTPI) in Thai breast- cancer patients. Asian Pac. J. Cancer Prev., 12, 10, 2731-4, (2011).

[18].G. Strathdee, M.J. MacKean, M. Illand, R. Brown, A role for methylation of the hMLH1 promoter in loss of hMLH1 expression and drug resistance in ovarian cancer. Oncogene., 18, 14, 2335-41 (1999).

[19].K. Terada, E. Okochi-Takada, S. AkashiTanaka, K. Miyamoto, K. Taniyama, H. Tsuda, K. Asada, M. Kaminishi, T. Ushijima, Association between frequent $\mathrm{CpG}$ island methylation and HER2 amplification in human breast cancers. Carcinogenesis, 30, 3, 466-71 (2009).

[20]. H.C. Yoon, S. Jing, D.G. Marilie, Z. YuJing, W. Qiao, G. Karina, X. Xinran, T.B. Patrick, L.T. Susan, G. Gail, H. Hanina, I.N. Alfred, C. Jia, M.S. Regina, Prognostic significance of gene-specific promoter hypermethylation in breast cancer patients. Breast Cancer Res. Treat., 131, 1, 197-205 (2012).

[21].B.L. Zhang, T. Sun, B.N. Zhang, S. Zheng, N. Lü, B.H. Xu, X. Wang, G.J. Chen, D.K. $\mathrm{Yu}$, D.X. Lin, Polymorphisms of GSTP1 is associated with differences of chemotherapy response and toxicity in breast cancer. Chin. Med. J., 124, 2, 199-204 (2011). 